\title{
Photo-oxidative killing of human colonic cancer cells using indocyanine green and infrared light
}

\author{
W Bäumler ${ }^{1}$, C Abels ${ }^{1}$, S Karrer, T Weiß ${ }^{3}$, H Messmann², M Landthaler ${ }^{1}$ and R-M Szeimies ${ }^{1}$ \\ Departments of ${ }^{1}$ Dermatology, ${ }^{2}$ Internal Medicine I and ${ }^{3}$ Surgery, University of Regensburg, 93042 Regensburg, Germany
}

\begin{abstract}
Summary Despite of the approval of Photofrin $®$ in various countries, chemically defined sensitizers for photodynamic therapy (PDT) are still needed for the absorption of light in the infrared spectrum, which provides a maximal penetration of light into tissue. Therefore, both the efficacy and the mechanism of action of the clinically approved dye indocyanine green (ICG) and laser irradiation were investigated in vitro. For the investigation of phototoxic effects, HT-29 cells were incubated $24 \mathrm{~h}$ prior to irradiation by using different concentrations of ICG $(10-500 \mu \mathrm{m})$. In each experiment, cells were irradiated using a continuous wave (cW)-diode laser $\left(\lambda_{\text {ex }}=805 \mathrm{~nm}, 30 \mathrm{~J} \mathrm{~cm}{ }^{-2}, 40 \mathrm{~mW} \mathrm{~cm}{ }^{-2}\right)$. After laser irradiation, cell viability of dark control and of cells incubated with $500 \mu \mathrm{M}$ ICG was $1.27 \pm 0.11$ or $0.28 \pm 0.05$ respectively. Using $100 \mu \mathrm{M}$ $I C G$ and $D_{2} \mathrm{O}$, cell viability was further decreased from $0.46 \pm 0.03\left(\mathrm{H}_{2} \mathrm{O}\right)$ to $0.11 \pm 0.01\left(\mathrm{D}_{2} \mathrm{O}\right)$. Using $\mathrm{D}_{2} \mathrm{O}$ and $100 \mu \mathrm{M} I C G$, the concentration of malondialdehyde, a marker of lipid peroxidation, increased from $0.89 \pm 0.10 \mathrm{nmol} 10^{-6}$ cells to $11.14 \pm 0.11 \mathrm{nmol} 10^{-6}$ cells. Using $100 \mu \mathrm{M}$ ICG and laser irradiation sodium azide or histidine $(50 \mathrm{~mm})$, quenchers of singlet oxygen reduced the cell killing significantly. In contrast, when using mannitol, a quencher of superoxide anion and hydroxyl radical, cell killing was not inhibited. According to the present results, photoactivated ICG seems to kill colonic cancer cells due to the generation of singlet oxygen and the subsequent formation of lipid peroxides. Therefore, ICG might present a promising photosensitizer for PDT; first clinical results confirm these findings.
\end{abstract}

Keywords: HT-29 cells; ICG; singlet oxygen; lipid peroxidation

Indocyanine green (ICG), which was approved by the United States Food and Drug Administration in 1956, is widely applied in medical diagnosis (Fox et al, 1956; Flower and Hochheimer, 1976; Moneta et al, 1987).

ICG shows a low incidence of adverse reactions (Hope-Ross et al, 1994) and has been intensively studied regarding its pharmacokinetics (Paumgartner et al, 1970). The absorption spectrum of this watersoluble, anionic tricarbocyanine dye exhibits a strong absorption band around $800 \mathrm{~nm}$ coinciding with the emission wavelength of a diode-laser (805 nm, see Figure 1).

For the evaluation of ICG as a possible photosensitizer, various photophysical parameters of ICG were determined by us in cooperation with the Department of Physics (University of Regensburg, Germany). The yields of triplet formation $\varphi_{\mathrm{S} 1-\mathrm{T} 1}$, by $\mathrm{S}_{1}-\mathrm{T}_{1}$ intersystem-crossing are $14 \%$ (in water, $\mathrm{H}_{2} \mathrm{O}$ ), $16 \%$ (in methanol), $17 \%$ (in dimethypl sulphoxide, DMSO) and 11\% (in aqueous albumin solution) (Reindl et al, 1997). In comparison to HPD (in methanol, $82 \%$ ) and aluminium phthalocyanine (in water, 38\%) (Grossweiner, 1994) the triplet yields of ICG appear low, but the values of ICG might be high enough to act as a photosensitizer for photodynamic therapy (PDT).

First, in vitro experiments using ICG and normal keratinocytes (Fickweiler et al, 1997) showed phototoxic effects. However, the mechanism of action - photo-oxidative versus photothermal cell killing - remained unclear and was investigated again using carcinoma cells (colon cancer, HT-29).

Received 19 June 1998

Revised 16 November 1998

Accepted 17 November 1998

Correspondence to: R-M Szeimies

\section{MATERIALS AND METHODS}

\section{Cell culture and dye preparation}

The immortalized human colon carcinoma cell line HT-29 (Fogh and Trempe, 1975) was maintained in Dulbecco's modified Eagle's medium (DMEM; Sigma Chemie, Deisenhofen, Germany) and supplemented with $10 \%$ fetal calf serum (FCS; Sigma Chemie), 1\% L-glutamine and 1\% streptomycin-penicillin (Gibco, Eggenstein, Germany) in a humidified atmosphere containing $8 \%$ carbon dioxide at $37^{\circ} \mathrm{C}$. Cells were washed with phosphatebuffered saline (PBS; Biochrom, Berlin, Germany) and harvested by a 10 min treatment with $0.05 \%$ trypsin $/ 0.02 \%$ EDTA (Gibco) in PBS. For in vitro assays, ICG (molar mass of the ICG sodium iodide: $924.9 \mathrm{~g} \mathrm{~mol}^{-1}$; PULSION Medizintechnik, München, Germany) was dissolved in growth medium at concentrations of $10,50,100$ and $500 \mu \mathrm{M}$.

\section{Treatment protocol and phototoxicity assay}

HT-29 cells were seeded at equal concentrations $\left(15 \times 10^{3}\right.$ cells in $100 \mu \mathrm{l}$ medium per well) into 96-well microtitre plates (Costar, Tecnomara, Fernwald, Germany). After overnight cell attachment, medium was replaced by $100 \mu \mathrm{I}$ ICG solution at various concentrations $(10,50,100$ or $500 \mu \mathrm{M})$. Following an incubation time of $24 \mathrm{~h}$ at $37^{\circ} \mathrm{C}$, supernatants were removed. In order to eliminate remaining dye, cells were carefully washed with medium and covered with $100 \mu \mathrm{l}$ of drug-free medium prior to irradiation. The cells for control experiments were processed in the same way.

Irradiation of cells incubated with ICG was performed using a continuous wave (cw)-diode-laser emitting light at $805 \mathrm{~nm}$ (Opto Power Corp., CA, USA) with a maximum optical output power of $15 \mathrm{~W}$. The laser light was coupled into a monocore fibre with $1.5 \mathrm{~mm}$ 
diameter and distributed to a flat homogeneous area $\left(150 \mathrm{~cm}^{2}, \varnothing 14\right.$ $\mathrm{cm}$ ) sufficient to cover a 96-well microtitre plate by a biconvex lens with a fluence of $40 \mathrm{~mW} \mathrm{~cm}$. The fluence used was $30 \mathrm{~J} \mathrm{~cm}^{-2}$. Measuring the temperature of supernatants by a thermocouple immediately after irradiation ensured that no hyperthermic conditions were imposed by this irradiation arrangement.

Following irradiation, cells were maintained under normal culture conditions for a further $24 \mathrm{~h}$. Viability of cells after ICG and/or light treatment was assessed by means of the 3-4,5dimethylthiazol-2,5-diphenyl tetrazolium bromide (MTT) assay (for details see McHale and McHale, 1988). The ratio of the optical densities of treated cells to untreated cells, which served as control, was referred to as cell viability (CV).

\section{Effect of sodium azide, histidine and mannitol on cell killing}

Sodium azide, histidine or mannitol effective physical quencher of reactive oxygen species (Moan et al, 1979; Agarwal et al, 1991; Hampton et al, 1993; Zaidi et al, 1993) were added to the cell culture $60 \mathrm{~min}$ prior to irradiation. HT-29 cells incubated with $100 \mu \mathrm{M}$ ICG for $24 \mathrm{~h}$ were irradiated $\left(30 \mathrm{~J} \mathrm{~cm}^{-2}\right)$ as described above but in presence of sodium azide, histidine or mannitol (Merck) at a concentration of $50 \mathrm{~mm}$ in PBS. CV was assessed as described above.

\section{Effect of $\mathrm{D}_{2} \mathrm{O}$ on cell killing}

Cell killing effects are enhanced using $\mathrm{D}_{2} \mathrm{O}$ in vitro (Lin et al, 1991). $\mathrm{D}_{2} \mathrm{O}$ was added $60 \mathrm{~min}$ prior to irradiation. HT-29 cells incubated with $100 \mu \mathrm{M}$ ICG for $24 \mathrm{~h}$ were irradiated $\left(30 \mathrm{~J} \mathrm{~cm}^{-2}\right)$ as described above but in presence of $\mathrm{D}_{2} \mathrm{O}$. $\mathrm{CV}$ was assessed as described above.

\section{Lipid peroxidation assay}

Unsaturated lipids are important targets of membrane photooxidation. Malondialdehyde (MDA), an ultimate marker of lipid peroxidation, can be measured by the fluorometric thiobarbituric acid (TBA) assay (Perret et al, 1994). After irradiation the cells were homogenized using ultrasound and centrifuged for $15 \mathrm{~min}$. The suspension was mixed with phosphortungstic acid $(10 \%$ in $\left.\mathrm{H}_{2} \mathrm{O}\right)$, sodium dodecyl sulphate $\left(7 \%\right.$ in $\left.\mathrm{H}_{2} \mathrm{O}\right)$, hydrochloric acid $(0.1 \mathrm{M})$, thiobarbituric acid $\left(0.5 \%\right.$ in $\left.\mathrm{H}_{2} \mathrm{O}\right)$ and shaken for $60 \mathrm{~min}$ at a temperature of $95^{\circ} \mathrm{C}$. After cooling down, the MDA-TBA complex was extracted by $n$-butanol. The quantification of the MDA-TBA complex was performed by measuring its fluorescence at $553 \mathrm{~nm}$; a MDA standard solution (0-3 nmol ml-1) served as control.

\section{Data analysis and statistics}

Each individual experiment was carried out at least in triplicate. For the MTT assay, at least ten individual wells were plated with cells treated in an identical matter with their mean optical density used for data analysis. The effects of the different treatment modalities were expressed as $\mathrm{CV}$ of treated cells compared with untreated controls. Differences were tested for statistical significance using the two-sided $t$-test. All primary data are presented as mean and standard deviations of the mean.

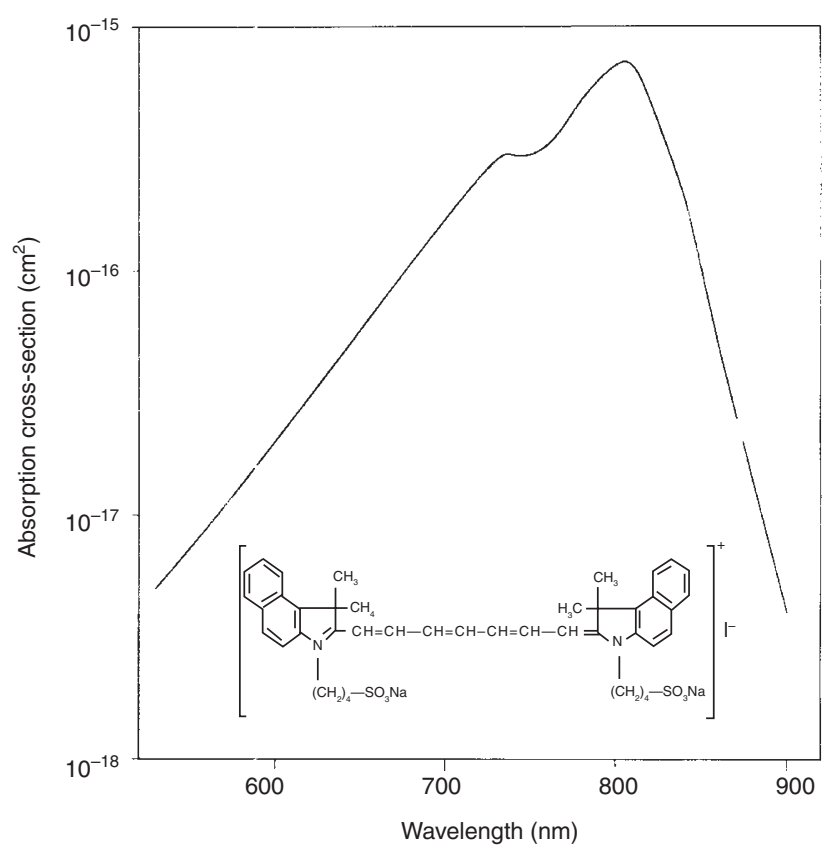

Figure 1 Chemical structure and absorption spectrum of ICG sodium iodide

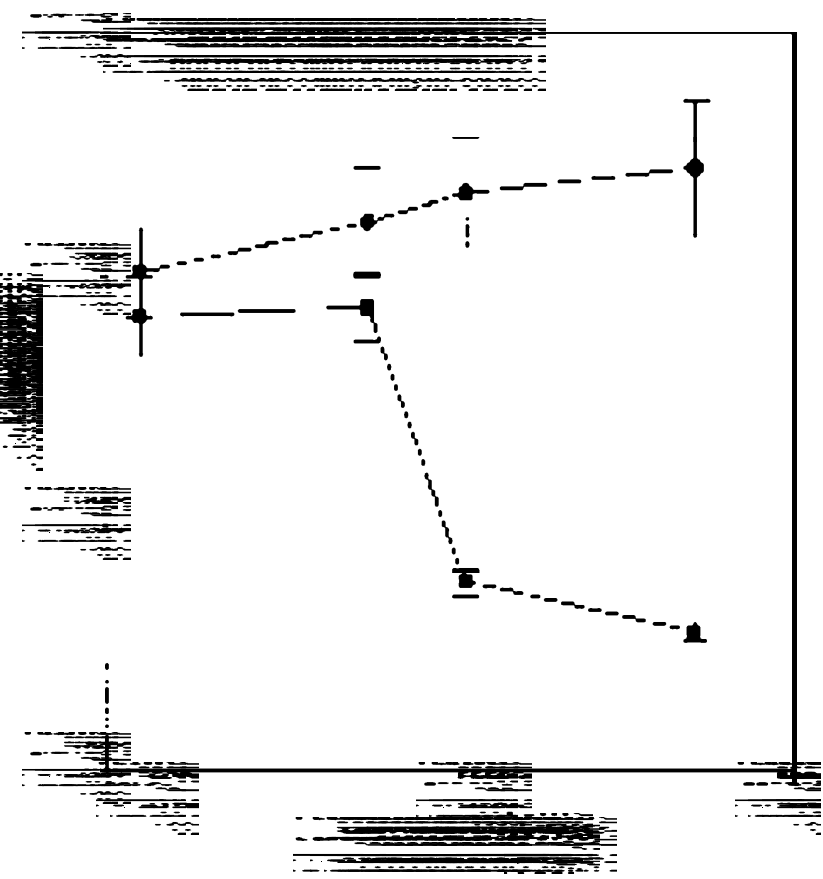

Figure 2 Concentration finding studies with $(\square)$ and without $(\boldsymbol{\bullet})$ irradiation by a cw-diode laser $\left(805 \mathrm{~nm}, 40 \mathrm{~mW} \mathrm{~cm}^{-2}, 30 \mathrm{~J} \mathrm{~cm}^{-2}\right)$. Cell viability of colonic cancer cells HT-29 following incubation for $24 \mathrm{~h}$ using different concentrations of ICG. Each point is the mean of at least three determinations \pm standard deviation

\section{RESULTS}

\section{ICG phototoxicity in vitro}

The experiments revealed no dark toxicity in any ICG concentration used. Irradiation used on its own did not result in a significant decrease of CV. Viability assays $24 \mathrm{~h}$ after irradiation exhibited a 


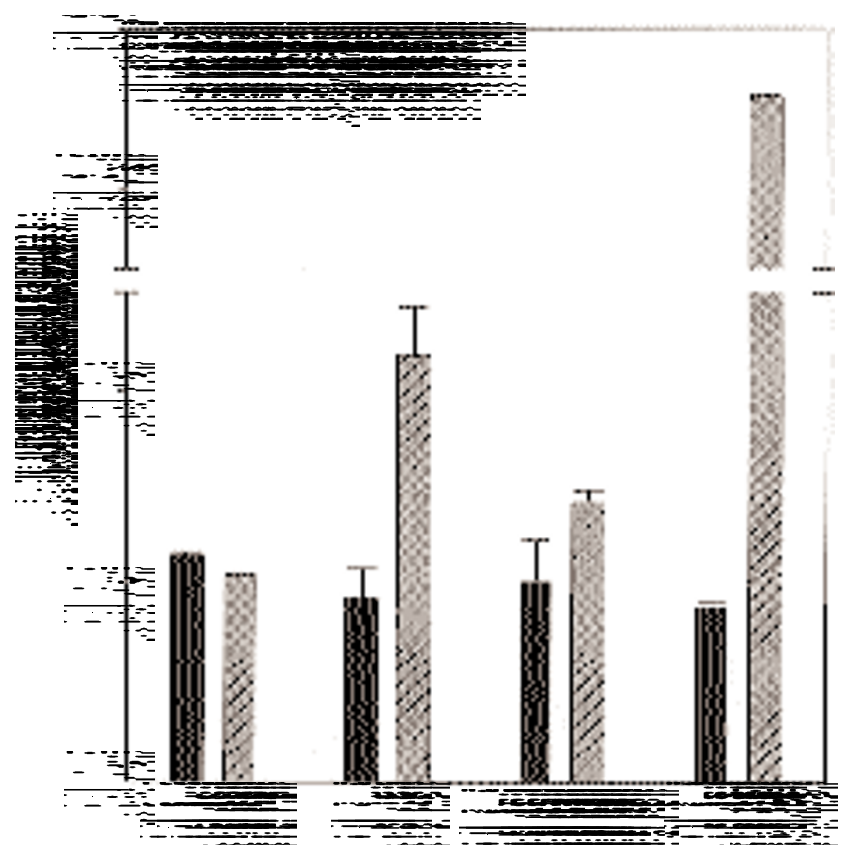

Figure 3 Effects of histidine $(50 \mathrm{mM})$ and $\mathrm{D}_{2} \mathrm{O}$ on ICG-incubated HT-29 cells (100 $\mu \mathrm{m}$ ICG) with and without light irradiation (diode-laser, $805 \mathrm{~nm}$, $40 \mathrm{~mW} \mathrm{~cm}^{-2}$ ). The black bars represent MDA concentration using ICG alone and ICG in combination with histidine or $\mathrm{D}_{2} \mathrm{O}$, the grey bars represent the MDA concentration using ICG alone and ICG in combination with histidine or $\mathrm{D}_{2} \mathrm{O}$ following irradiation. Each bar is the mean of 3 determinations \pm standard deviation

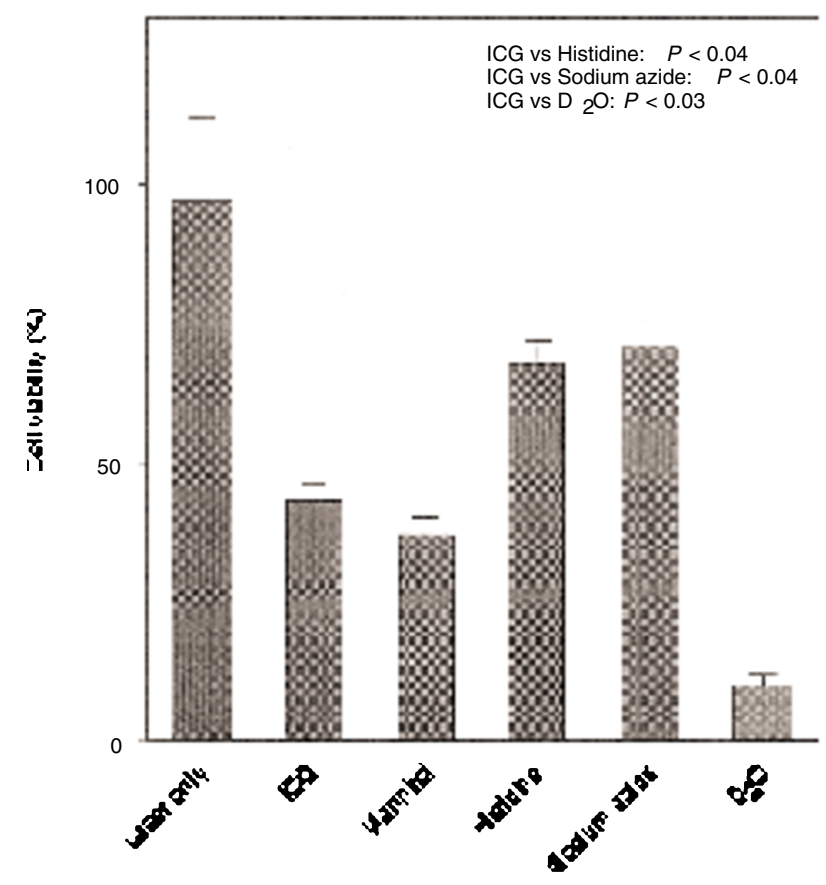

Figure 4 Effect of sodium azide $(50 \mathrm{~mm})$, histidine $(50 \mathrm{~mm})$ mannitol $(50 \mathrm{~mm})$ and $\mathrm{D}_{2} \mathrm{O}$ on ICG $(100 \mu \mathrm{M})$ mediaed cell killing determined by the MTT assay (incubation time $24 \mathrm{~h}$, total light dose $30 \mathrm{~J} \mathrm{~cm}^{-2}$ ). Each bar is the mean of three determinations \pm standard deviation

behaviour inversely proportional to the used ICG concentrations as illustrated in Figure 2. Starting with a concentration of $10 \mu \mathrm{M} \mathrm{ICG,}$ the $\mathrm{CV}$ decreased according to an increasing ICG concentration by using a light dose of $30 \mathrm{~J} \mathrm{~cm}^{-2}$. CV of dark control and cells incubated with $500 \mu \mathrm{M}$ ICG and irradiated with $30 \mathrm{~J} \mathrm{~cm}^{-2}$ was $1.27 \pm 0.14$ and $0.28 \pm 0.02$ respectively.

\section{Lipid peroxidation}

MDA, a marker for lipid peroxidation, increased from $0.93 \pm 0.16$ nmol $10^{-6}$ cells to $2.17 \pm 0.26 \mathrm{nmol} 10^{-6}$ cells after light irradiation $\left(30 \mathrm{~J} \mathrm{~cm}^{-2}\right.$ ) of HT-29 cells incubated with $100 \mu \mathrm{M}$ ICG for $24 \mathrm{~h}$ (Figure 3). Using histidine, the amount of MDA was $1.42 \pm 0.05$ nmol $10^{-6}$ cells with light and $1.01 \pm 0.24 \mathrm{nmol} 10^{-6}$ cells without light. Adding $\mathrm{D}_{2} \mathrm{O}$, however, dramatically increased MDA from $0.89 \pm 0.10 \mathrm{nmol} 10^{-6}$ cells to $11.14 \pm 0.11 \mathrm{nmol} 10^{-6}$ cells.

\section{Effects of different quenchers and $\mathrm{D}_{2} \mathrm{O}$ on cell killing}

Figure 4 shows the effect of incubation with ICG $(100 \mu \mathrm{M})$ and quenchers $(50 \mathrm{mM})$ or $\mathrm{D}_{2} \mathrm{O}$ prior to light irradiation $\left(30 \mathrm{~J} \mathrm{~cm}^{-2}\right)$. Using ICG and laser irradiation only, CV was $0.46 \pm 0.03$. The cell killing of ICG was reduced in the presence of sodium azide indicated by an increase of the CV from $0.46 \pm 0.03$ to $0.65 \pm 0.04$. In the presence of histidine, $\mathrm{CV}$ increased from $0.46 \pm 0.03$ to $0.64 \pm 0.05$. By adding $50 \mathrm{~mm}$ mannitol to the cells, $\mathrm{CV}$ did not change significantly, $0.46 \pm 0.03$ and $0.40 \pm 0.04$ respectively, whereas the addition of $\mathrm{D}_{2} \mathrm{O}$ revealed a dramatic decrease of $\mathrm{CV}$ from $0.46 \pm 0.03$ to $0.11 \pm 0.06$.

\section{DIscussion}

The present results show that human colon carcinoma cells can be effectively destroyed by photoactivated ICG. Irradiation with a low energy density $\left(30 \mathrm{~J} \mathrm{~cm}^{-2}\right)$ significantly decreased the cell viability. Other experiments in vitro using different sensitizers and a different setup, yielded a similar cell toxicity (Ma et al, 1994; Jori, 1996; Rossi et al, 1996; Fickweiler et al, 1997). However, ICG concentrations up to $500 \mu \mathrm{M}$ did not exhibit a dark toxicity. The photosensitizers used, e.g. haematoporphyrin (Bachor et al, 1995), methylene blue (Wainwright et al, 1997) or porphycenes (Bäumler et al, 1995), usually resulted in an increasing dark toxicity with increasing sensitizer concentrations in vitro.

Evaluating the mechanism of action regarding the cell killing by a photosensitizer, specific experiments should be performed since the absorbed energy of the laser light by the molecule of the used photosensitizer can reach the ground state by either radiative (fluorescence) or non-radiative decay. In the non-radiative decay the absorbed energy of the molecule is converted either to heat (internal conversion) and transferred to other molecules (photooxidation, type I), or transferred to molecular oxygen (photooxidation, type II) via triplet-state.

Photothermal effects due to internal conversion damage cells by an increase of the intracellular temperature, shown by the use of ICG for photocoagulation or tissue welding (Decoste et al, 1992; Reichel et al, 1994). If photothermal effects are responsible for cell killing by ICG, quenchers like sodium azide or histidine should fail to reduce ICG-induced phototoxicity.

In order to investigate whether photo-oxidation of type I or type II are the predominant mechanisms of action mannitol, a quencher of superoxide anion, hydroxyle radical (type I) and histidine or sodium azide, quenchers of singlet oxygen (type II) were used (Agarwal et al, 1991; Zaidi et al, 1993; Wlaschek et al, 1995). The results seen in Figure 4 show that mannitol did not protect HT-29 cells against photoactivated ICG, whereas the quenchers sodium 
azide or histidine significantly reduced the cell killing. Thus, in the present in vitro experiments, the killing of HT-29 cells by ICG and laser irradiation seem to be mediated mainly by singlet oxygen. Moreover, adding $\mathrm{D}_{2} \mathrm{O}$ to the culture medium, photo-oxidative cell killing was further enhanced due to a prolonged lifetime of singlet oxygen in the presence of $\mathrm{D}_{2} \mathrm{O}$, about $40 \mu$ s versus $3 \mu \mathrm{s}$ in $\mathrm{H}_{2} \mathrm{O}$ (Matheson et al, 1978). In addition, the increase of lipid peroxides in vitro as measured by means of the fluorometric TBA assay (Perret et al, 1994), confirms that photo-oxidation of HT-29 cell structures is responsible, to some extent, for the cell killing in the chosen experimental setup (Figure 3). The increase of MDA adding $\mathrm{D}_{2} \mathrm{O}$ to the cell culture medium may be a hint for oxidative destruction of membranes due to the presence of singlet oxygen and its prolonged lifetime in $\mathrm{D}_{2} \mathrm{O}$.

In contrast to many other sensitizers, e.g. porphyrine derivatives, which are photoactivated by red light ranging from 600 to $700 \mathrm{~nm}$, ICG exhibits a high absorption cross-section in the infrared region at $805 \mathrm{~nm}$. Infrared light penetrates deeper into tissue than red light (Anderson et al, 1981), presenting an outstanding advantage, if ICG acts as a photosensitizer in vivo.

Due to the clinical approval of ICG, the successful treatment of Kaposi's sarcomas was already shown in a first pilot study, using a different experimental setup (Abels et al, 1998). Further investigations regarding the exact mechanism of action in vivo - photodynamic versus photothermal - will be performed.

\section{ACKNOWLEDGEMENTS}

We acknowledge technical assistance of $\mathrm{P}$ Weiderer.

\section{REFERENCES}

Abels C, Karrer S, Bäumler W, Goetz AE, Landthaler M and Szeimies RM (1998) Indocyanine green and laser light for the treatment of AIDS-associated cutaneous Kaposi's sarcoma. Br J Cancer 77: 1021-1024.

Agarwal R, Athar M, Urban SA, Bickers DR and Mukhtar H (1991) Involvement of singlet oxygen in chloroaluminum phthalocyanine tetrasulfonate-mediated photoenhancement of lipid peroxidation in rat epidermal microsomes. Cancer Lett 56: 125-129

Anderson R, Hu J and Parrish J (1981) Optical radiation transfer into human skin. In Bioengeneering and the Skin, Marks R, Payne P (eds), pp. 253-265. Lancaster MTP, Boston, USA

Bachor R, Reich E, Miller K, Rück A and Hautmann R (1995) Photodynamic efficiency of liposome-administered tetramethyl hematoporphyrin in two human bladder cancer cell lines. Urol Res 23: 151-156

Bäumler W, Szeimies RM, Abels C, Karrer S and Landthaler M (1995) ${ }^{9}$ acetoxy2,7,12,17-tetrakis-( $\beta$-methoxyethyl)-porphycene (ATMPn), a novel photosensitizer for photodynamic therapy - dose-dependent effects in vitro. In Photochemotherapy: Photodynamic Therapy and Other Modalities, Ehrenberg B, Jori G, Moan J, (eds). Proc. SPIE 2625: 315-318

Decoste S, Farinelli W, Flotte T and Anderson R (1992) Dye-enhanced laser welding for skin closure. Laser Surg Med 12: 25-32
Fickweiler S, Szeimies R-M, Bäumler W, Steinbach P, Karrer S, Goetz A-E, Abels C, Hofstädter F and Landthaler M (1997) Indocyanine green: intracellular uptake and phototherapeutic effects. J Photochem Photobiol B 38: 178-183

Flower R and Hochheimer B (1976) Indocyanine green dye fluorescence and infrared absorption choroidal angiography performed simultaneously with fluorescein angiography. Johns Hopkins Med J 138: 33-42

Fogh J and Trempe G (1975) In Human Tumor Cells In Vitro Fogh J (ed), pp. 115-159. Plenum Press: New York

Fox I, Brooker G, Heseltine D, Essex H and Wood E (1956) New dyes for continuous recording of dilution curves in whole blood independent of variations in blood oxygen saturation. Am J Physiol 187: 599

Grossweiner L (1994) Science of Phototherapy. CRC Press: London

Hampton J, Skalkos D, Taylor P and Selman S (1993) Iminium salt of copper benzochlorin (CDS1), a novel photosensitizer for photodynamic therapy: mechanism of cell killing. Photochem Photobiol 58: 100-105

Hope-Ross M, Yannuzzi L, Gragoudas E, Guyer D, Slakter J, Sorenson J, Krupsky S, Orlock D and Puliafito C (1994) Adverse reactions due to indocyanine green. Ophthalmology 101: 529-533

Jori G (1996) Tumour photosensitizers: approaches to enhance the selectivity and efficiency of photodynamic therapy. J Photochem Photobiol B 36: 87-93

Lin CW, Shulok JR, Wong YK, Schanbacher CF, Cincotta L and Foley JW (1991) Photosensitization, uptake and retention of phenoxazine nile blue derivatives in human bladder carcinoma cells. Cancer Res 51: 1109-1116

McHale A and McHale D (1988) Use of a tetrazolium based colorimetric assay in assessing photoradiation therapy in vitro. Cancer Lett 41: 315-321

Ma L, Moan J and Berg K (1994) Evaluation of a new photosensitizer, meso-tetrahydroxyphenyl-chlorin, for use in photodynamic therapy: a comparison of its photobiological properties with those of two other photosensitizers. Int $J$ Cancer 57: 883-888

Matheson IB, Lee J and King AD (1978) The lifetime of singlet oxygen in heavy water. Chem Phys Lett 55: 49

Moan J, Pettersen E and Christensen T (1979) The mechanism of photodynamic inactivation of human cells in vitro in the presence of haematoporphyrin. Br J Cancer 39: 398-407

Moneta G, Brülisauer M, Jäger K and Bollinger A (1987) Infrared fluorescence videomicroscopy of skin capillaries with indocyanine green. Int J Microcirc Clin Exp 6: 25-34

Paumgartner G, Probst P, Kraines R and Leevy C (1970) Kinetics of indocyanine green removal from the blood. NY Acad Sci 170: 134-170

Perret C, Foultier MT, Vonarx-Coinsman V, Quancard O, Combre A and Patrice T (1994) Malondialdehyde dosimetry in laser-irradiated tissues sensitized by hematoporphyrin derivative. J Pharmacol Exp Ther 269: 787-791

Reichel E, Puliafito C, Duker J and Guyer D (1994) Indocyanine green dyeenhanced diode laser photocoagulation of poorly defined subfoveal choroidal neovascularization. Ophthalm Surg 25: 195-201

Reindl S, Penzkofer A, Gong S-H, Landthaler M, Szeimies R-M, Abels C and Bäumler W (1997) Quantum yield of triplet formation for indocyanine green. J Photochem Photobiol A 105: 65-68

Rossi FM, Campbell DL, Pottier RH, Kennedy JC and Dickson EF (1996) In vitro studies on the potential use of 5-aminolaevulinic acid-mediated photodynamic therapy for gynaecological tumours. Br J Cancer 74: 881-887

Wainwright M, Phoenix DA, Rice L, Burrow SM and Waring J (1997) Increased cytotoxicity and phototoxicity in the methylene blue series via chromophore methylation J Photochem Photobiol B 40: 233-239

Wlaschek M, Briviba K, Stricklin GP, Sies H and Scharffetter-Kochanek K (1995) Singlet oxygen may mediate the ultraviolet A-induced synthesis of interstitial collagenase. J Invest Dermatol 104: 194-198

Zaidi SI, Agarwal R, Eichler G, Rihter BD, Kenney ME and Mukhtar H (1993) Photodynamic effects of new silicon phthalocyanines: in vitro studies utilizing rat hepatic microsomes and human erythrocyte ghosts as model membrane sources. Photochem Photobiol 58: 204-210 